\title{
EFFECTS OF LEUKEMIA INHIBITORY FACTOR ON TRANSCRIPT EXPRESSION OF PLURIPOTENT GENES IN BOVINE EMBRYONIC STEM LIKE CELLS
}

\author{
Le Thanh Long ${ }^{1 *}$, Ho Nguyen Quynh $\mathrm{Chi}^{2}$, Hoang Nghia Son ${ }^{1}$ \\ ${ }^{1}$ Institute of Tropical Biology, VAST, *lelong2510@gmail.com \\ ${ }^{2}$ International University, Vienam National University, Ho Chi Minh city
}

\begin{abstract}
Leukemia inhibitory factor (Lif) is very important for embryonic stem cell establishment. In this study, we investigated effects of Lif on transcript expression of pluripotent genes of bovine embryonic stem like cells in passage 1, passage 3 and passage 6 . The results showed that Lif supplementation of medium could improve transcript expression of pluripotent gene including nanog, oct4, sox 2 and $c$-myc. Three Lif concentrations were applied for cell culture medium. We found that pluripotent gene transcripts were highest expressed in $10^{3} \mathrm{IU} / \mathrm{ml}$ Lif supplemented medium, especially nanog and oct 4 transcript expression could be maintained until $6^{\text {th }}$ passage . The transcript expression was decreased in $10^{4} \mathrm{IU} / \mathrm{ml}$ Lif suppmented medium, suggesting that high concentration of Lif could inhibit pluripotent gene expression. Thus, $10^{3} \mathrm{IU} / \mathrm{ml}$ Lif was the most efficient concentration to improve transcript expression of pluripotent genes. There was a relationship in nanog expression and $c$-myc and sox 2 expression. $C$-myc and sox 2 expression were up-regulated when nanog was down-regulated. We also accessed nanog or oct 4 which were key factors for the maintenace of pluripotency and renewal of bovine embryonic stem like cell. The result demonstrated that nanog could be the key factor for pluripotency of bovine embryonic stem like cells.
\end{abstract}

Keywords: bovine embryonic stem cells, leukemia inhibitory factor (Lif), pluripotent genes, rt-pcr, transcript expression.

\section{INTRODUCTION}

Embryonic stem cells are pluripotent cells which could be derived from embryos at blastocyst stage. They have two characteristics including pluripotency and renewal. They can differentiate into more than 200 cell types in our body [3]. Embryonic stem cells express specific markers or characteristics, such as stage specific embryonic antigens, enzymatic activities including alkaline phosphatase and telomerase and pluripotent genes including oct4, nanog, sox2, c-myc [2]. Embryonic stem cells can differentiate in vivo and in vitro in teratomas into cells representing the three major germ layers: endoderm, mesoderm or ectoderm [8]. These pluripotent genes profile and pluripotency have been clearly characterized in mouse, human and primate embryonic stem cells. However, these characteristics have been unclear in ungulates, especially bovine. Bovine embryonic stem cell lines have not been stably established because there was no medium being suitable to maintain pluripotency and renewal of these cells [6]. One of the most important factors to maintain embryonic stem cell line is leukemia inhibitory factor. Leukemia inhibitory factor can maintain pluripotent gene expression such as oct4, nanog, sox2, c-myc to maintain pluripotency of embryonic stem cells. Thus, in this study, we aim to access effect of leukemia inhibitory factor on transcript expression of pluripotent genes in bovine embryonic stem like cells.

\section{MATERIALS AND METHODS}

\section{Blastocyst production}

Bovine ovaries were collected from slaughterhouse then transported to laboratory. Aspiration method was applied to collect cumulus oocyte complexes (COCs). COCs were cultured in TCM199 supplemented with 10\% fetal bovine serum, 0.1 IU LF, 0.1IU FSH and $1 \% \mathrm{pen} / \mathrm{strep}$ in 22-24 hours. Mature oocytes were fertilized in Fert-TALP medium with sperm in 6-8 hours [5]. Sperm density was $10^{6}$ sperm $/ \mathrm{ml}$. Fertilized oocytes were culture in Soffa medium [7]. 


\section{Feeder layer preparation}

Pregnant mouse at $12.5 \mathrm{E}$ was used to isolated mouse embryonic fibroblast. Fetus were collected and washed in phosphate buffer solution to discard blood. Head, arms, legs and internal organs were removed. The remained tissues were washed in phosphate buffer solution. These tissues were minced and trypsinized in trypsin-EDTA 0.25 medium to produce single cells. The single cell suspension was transferred to $\varphi 35 \mathrm{~mm}$ dishes containing 2 ml DMEM supplemented $10 \%$ fetal bovine serum, $1 \%$ Pen/Strep. To produce feeder layer, mouse embryonic fibroblast was incubated in $10 \mu \mathrm{g} / \mathrm{ml}$ mitomycin $\mathrm{C}$ supplemented medium in 2.5 hours. The mouse embryonic fibroblast was washed twice in DMEM supplemented with $10 \%$ fetal bovine serum, $1 \%$ Pen/Strep.

\section{Embryonic stem like cell culture}

Blastocyst embryos were denuded using 5 $\mu \mathrm{g} / \mathrm{ml}$ pronase in $2 \mathrm{~min}$ and transferred into mouse embryonic fibroblast inactivated by mytomycin C $10 \mu \mathrm{g} / \mathrm{ml}$. Embryonic stem like colonies were picked up and trypsinized in $0.25 \%$ trypsin-EDTA medium, then single cells were transferred into new mouse embryonic fibroblast inactivated by mytomycin C $10 \mu \mathrm{g} / \mathrm{ml}$. Bovine embryonic stem like cells were used to access colonic morphology, proLiferation and transcript expression of pluripotent genes.

\section{RT-PCR and semi-quantitative analysis}

Total mRNA was isolated using Trizol. RTPCR was applied to amplify pluripotent genes including nanog (Forward primer: GTGTTTGGTGAACTCTCCTG, Reverse primer: GGGAATTGAAATACTTGACAG), oct4 (Forward primer: GTTCTCTTTGGAAA GGTGTTC, Reverse primer: ACACTCGGACC ACGTCTTTC), $c-m y c$ (Forward primer: CGCG GTCGCCTCCTTCTCGCCCAGG, Reverse primer: GTCCGGGGAAGCGCAGGGC), sox2 (Forward primer: CATCCACAGCAAATGAC AGC, Reverse primer: TTTCTGCAAAGCTCC TACCG), and beta actin (Forward primer: GG AATCCTGTGGCATCCATGAAAC, Reverse primer: AAAACGCAGCTCAGTAACAGTC $\mathrm{CG})$. The RT reaction was performed in $42^{\circ} \mathrm{C}$ in $45 \mathrm{~min}$. The PCR reaction included an initial denaturation at $94^{\circ} \mathrm{C}$ for $5 \mathrm{~min}$ followed by 30 cycles of denaturation at $94^{\circ} \mathrm{C}$ for $1 \mathrm{~min}$, annealing at $58^{\circ} \mathrm{C}$ for $45 \mathrm{~s}$, and extension at $72^{\circ} \mathrm{C}$ for $75 \mathrm{~s}$, followed by final extension at $72^{\circ} \mathrm{C}$ for $5 \mathrm{~min}$. Amplicons were separated through a $1 \%$ agarose gel at $100 \mathrm{~V}$ for $1 \mathrm{~h}$. Image $\mathbf{J}$ software was applied to analyze onedimensional electrophoretic gels [1].

\section{RESULTS AND DISCUSSION}

\section{Effect of Lif on transcript expression of pluripotent genes in passage 1}

Bovine embryonic stem like cells in passage 1 expressed transcript of pluripotent genes in culture medium with and without Lif (figure 1). The nanog expression in control group was lower than Lif supplemented groups. Embryonic stem like cells in $10^{3} \mathrm{IU} / \mathrm{ml}$ Lif supplemented medium expressed nanog transcripts higher in $10^{2}$ and $10^{4} \mathrm{IU} / \mathrm{ml} \mathrm{Lif}$ supplemented media. There were no differences in oct 4 transcript expression in control group and group in $10^{2}$ and $10^{4} \mathrm{IU} / \mathrm{ml}$ Lif supplemented media. However, oct4 transcript expression was highest in embryonic stem like cells cultured in medium with $10^{3} \mathrm{IU} / \mathrm{ml}$ Lif. In control group, $c-m y c$ transcript expression was lower than that in $10^{2}$ and $10^{4} \mathrm{IU} / \mathrm{ml}$ Lif supplemented groups. The $c-m y c$ transcript was highest expressed in bovine embryonic stem like cells cultured in $10^{3} \mathrm{IU} / \mathrm{ml}$ Lif supplemented medium. Sox-2 transcript expression in bovine embryonic stem like cells culture in $10^{3}$ and $10^{4} \mathrm{IU} / \mathrm{ml}$ Lif supplemented medium were higher than in control and $10^{2}$ IU/ml Lif supplemented medium.

Effect of Lif on transcript expression of pluripotent genes in passage 3

In passage 3 , the transcript expression in almost bovine embryonic stem like cells groups were decreased (figure 2). The nanog transcript expression in control group and $10^{2}$ and $10^{4}$ $\mathrm{IU} / \mathrm{ml}$ Lif group were lower than that in $10^{3}$ IU/ml Lif group. There were no differences in nanog transcript expression between groups in passage 3 and passage 1 . The bovine embryonic stem like cells cultured in $10^{3} \mathrm{IU} / \mathrm{ml}$ Lif supplemented medium highest expressed nanog 
transcript. The oct4 transcript expression almost decreased in control group and $10^{2}$ and $10^{4}$ $\mathrm{IU} / \mathrm{ml}$ Lif supplemented group and were lower than bovine embryonic stem like cells in passage 1. However, the oct4 transcript was high expressed in $10^{3} \mathrm{IU} / \mathrm{ml}$ Lif supplemented group. The $c-m y c$ and sox-2 transcript expression of bovine embryonic stem like cells in passage 3 were lower than passage 1 but still high in $10^{3} \mathrm{IU} / \mathrm{ml}$ Lif supplemented group.
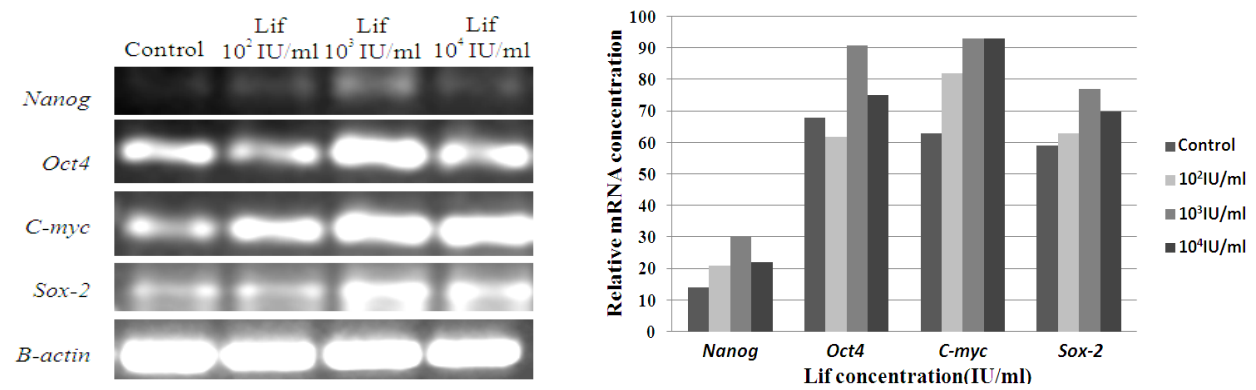

Figure 1. Effect of Lif on transcript expression of pluripotent genes of bovine embryonic stem like cellss in passage 1

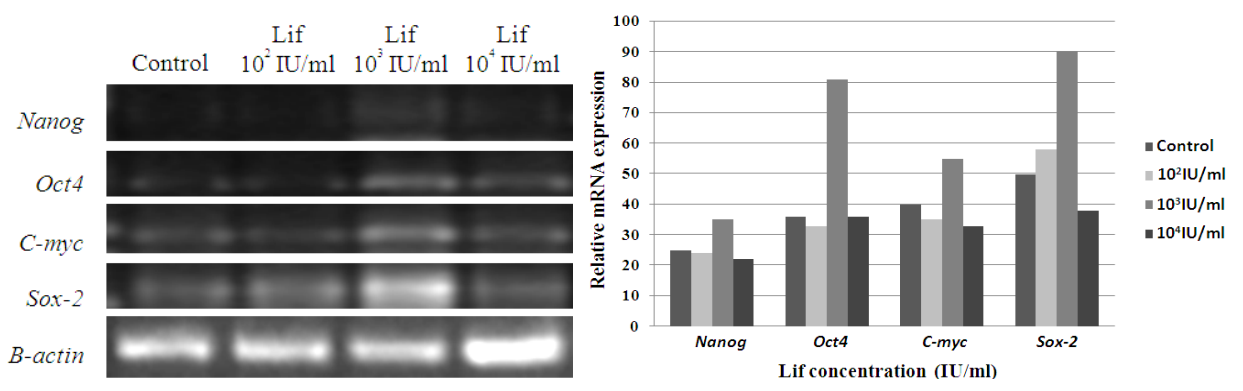

Figure 2. Effect of Lif on transcript expression of pluripotent genes of bovine embryonic stem like cellss in passage 3

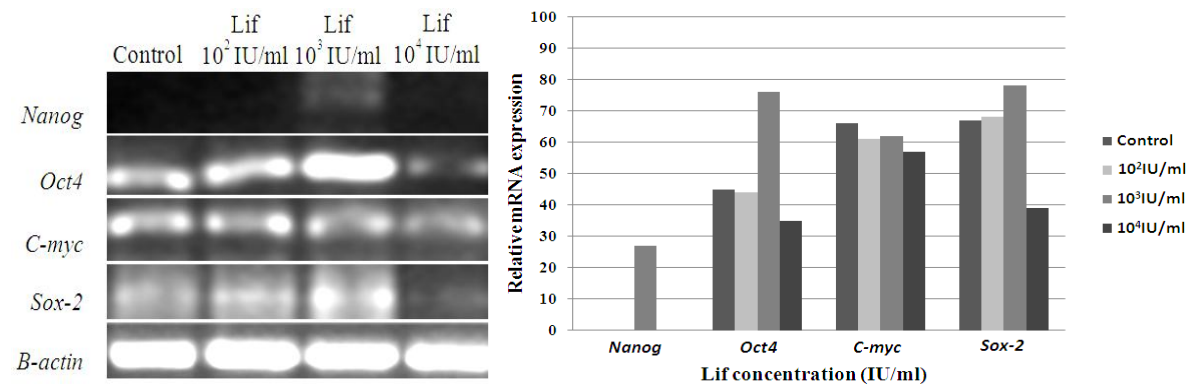

Figure 3. Effect of Lif on transcript expression of pluripotent genes of bovine embryonic stem like cellss in passage 6 .

Effect of Lif on transcript expression of pluripotent genes in passage 6

The nanog transcript expression was observed only in bovine embryonic stem like cells cultured in $10^{3} \mathrm{IU} / \mathrm{ml}$ Lif supplemented medium. There was no nanog transcript expression in the other groups. In passage 6, the oct 4 transcript expression in control and $10^{2}$ $\mathrm{IU} / \mathrm{ml}$ Lif supplemented groups were higher than those in $10^{4} \mathrm{IU} / \mathrm{ml}$ Lif supplemented group. The $c-m y c$ and sox-2 transcript expression of bovine embryonic stem like cells in passage 6 were increased higher than in passage 3 . The control group and Lif supplemented groups have the same $c-m y c$ transcript expression. The 
sox-2 transcript was low expressed in bovine embryonic stem like cells cultured in $10^{4} \mathrm{IU} / \mathrm{ml}$ Lif supplemented medium.

\section{Discussion}

Medium has played very important role in embryonic stem cell establishment, especially bovine embryonic stem cell. Embryonic stem cell medium could be modified based on animal. One of the most important factors in culture medium is leukemia inhibitory factor. Lif maintains pluripotent characteristics of mouse embryonic stem cell [12], but differentiated factor in human embryonic stem cells [10]. In bovine embryonic stem cell establishment, role of Lif was still unclear. Preliminary studies showed that Lif could maintain bovine embryonic stem cells [3], but another studies demonstrated that Lif did not improve the establishment of bovine embryonic stem cell lines [11]. Thus, it is very important to detect the role of Lif.

In this study, we found that Lif clearly effected on transcript expression of pluripotent genes in bovine embryonic stem like cells. The nanog, oct4, c-myc and sox-2 transcripts were highest expressed in bovine embryonic stem like cells cultured in $10^{3} \mathrm{IU} / \mathrm{ml}$ Lif supplemented medium. Bovine embryonic stem cell in control group had lower transcript expression than Lif supplemented groups. In the other hand, the transcript expression of pluripotent genes was suppressed in medium supplemented with high concentration of Lif $\left(10^{4} \mathrm{IU} / \mathrm{ml}\right)$. Thus, high concentration is not suitable for Lif to improve pluripotent gene expression in passage 1. Almost plutipotent genes had low transcript expression in passage 3 , suggesting that cell passage could effect on pluripotent gene expression and begin induce the degeneration of bovine embryonic stem like cells. However, $10^{3} \mathrm{IU} / \mathrm{ml}$ Lif supplemented medium maintained high expression of nanog, oct4, sox 2 and c-myc in bovine embryonic stem like cells in passage 3 . In passage 6 , only $10^{3}$ $\mathrm{IU} / \mathrm{ml}$ Lif supplemented medium could maintain nanog transcript expression, in other groups nanog transcript could not observed. The transcript of oct4, sox2 and c-myc were still highly expressed in medium supplemented with
$10^{3} \mathrm{IU} / \mathrm{ml}$ Lif. In this passage, the results also showed that nanog transcript of bovine embryonic stem like cells in control and $10^{2}$ and $10^{3} \mathrm{IU} / \mathrm{ml}$ Lif supplemented groups was not expressed, but $c-m y c$ and sox2 transcript expression was increased and was higher than those in passage 3 . It suggested that there was a relationship in nanog expression and sox 2 and c-myc expression.

Nanog and oct4 are very important to maintain pluripotency and renewal in embryonic stem cell. Oct4 is key factor to maintain pluripotent characteristics of mouse, rat, human and primate embryonic stem cell lines, but different from ungulates such as porcine, in which nanog is a key factor to pluripotency (Talbot, 2007). The key factor which maintains pluripotency of bovine embryonic stem like cells has been unclear. In passage 6 , when the degenerated bovine embryonic stem like cells did not express nanog transcript in control group and $10^{2}$ and $10^{3} \mathrm{IU} / \mathrm{ml}$ Lif supplement groups, but the $10^{3} \mathrm{IU} / \mathrm{ml}$ Lif supplemented medium could maintain nanog transcript. Whereas, oct4 transcript was highly expressed in passage 1,3 , and 6 , eventhough bovine embryonic stem like cells degenerated. The previous studies showed that nanog was a key factor for pluripotency of bovine induced pluripotent stem cell, and nanog improved pluripotent characteristics of bovine induced pluripotent stem cell [9]. It suggested that nanog could be a key factor for pluripotency of bovine embryonic stem like cells.

\section{CONCLUSION}

Leukemia inhibitory factor improved transcript expression of pluripotent genes in bovine embryonic stem like cells.

Acknowledgements: We are grateful to Department of Science and Technology of Ho Chi Minh city to financial support for this study.

\section{REFFERENCES}

1. Ahjoku A. O., Yu C. R., Liu X., Rashid M. M., Grace L. C., Robert B. N., Igal G., Lee Y. S., Charles E. E., 2007. $\mathrm{T}_{\mathrm{H}} 17$ cells contribute to uveitis and scleritis and are expanded by IL-2 and inhibited by IL27/STAT1. Nature Medicine, 13: 711-718. 
2. Byrne J. A., Mitalipov S. M., Wolf D. P., 2006. Current progress with primate embryonic stem cells. Curr. Stem. Cell. Res. Ther., 1: 127-138.

3. Evans M. J., Kaufman M. H., 1981. Establishment in culture of pluripotential cells from mouse embryos. Nature, 292: 154-156.

4. Keefer C. L., Pant D., Blomberg L., Talbot N. C., 2007. Challenges and prospects for the establishment of embryonic stem cell lines of domestic ungulates. Anim. Reprod. Sci., 98: 147-168.

5. Levent K., Gabriela P., Anna M., Karen N., Akif C., Iqbal K., Benjamin G. B., 2002. Bovine blastocyst development from oocytes injected with freeze-dried spermatozoa. Biol. Reprod., 67: 409-415.

6. Meenambigai T. V., Seijian V., 2011. Insights into embryonic stem cells of Bovines. Asian Journal of Animal Siences, 5: $1-18$

7. Orsi N. M., Leese H. J., 2004. Amino acid metabolism of preimplantation bovine embryos cultured with bovine serum albumin or polyvinyl alcohol.
Theriogenology, 15: 561-72.

8. Savatier P., Huang S., Szekely L., Wiman K. G., Samarut, 1994. Contrasting patterns of retinoblastoma protein expression in mouse embryonic stem cells and embryonic fibroblasts. Oncogene, 9: 809-818.

9. Sumer H., Liu J., Malaver-Ortega L. F., Lim M. L., Khodadadi K., Verma P. J., 2011. Nanog is a key factor for induction of pluripotency in bovine adult fibroblasts. J. Anim. Sci., 89: 2708-2716.

10. Takahashi K., Tanabe K., Ohnuki M., Narita M., Ichisaka T., Tomoda K., Yamanaka S., 2007. Induction of Pluripotent Stem Cells from Adult Human Fibroblasts by Defined Factors. Cell, 131: 861-872.

11. Vackova I. A., Lopes F., 2007. Putative embryonic stem cell lines from pig embryos. J. Reprod. Dev., 53: 1137-1149.

12. Wakayama S., Hikichi T., Suetsugu R., Sakaide Y., Bui H. T., Mizutani E., Wakayama T., 2006. Efficient establishment of mouse embryonic stem cell lines from single blastomeres and polar bodies. Stem Cells, 25: 986-93.

\title{
ẢNH HƯởNG CỦA NHÂN TỐ ỨC CHẾ BỆNH BACH CÀU LÊN SỰ BIỂU HIỆN CỦA MộT SỐ GENE ĐA TIỀM NĂNG CỦA TÊ BÀO GỐC PHÔI Bò
}

\author{
Lê Thành Long ${ }^{1}$, Hồ Nguyễn Quỳnh $\mathrm{Chi}^{2}$, Hoàng Nghĩa Sơnn ${ }^{1}$ \\ ${ }^{1}$ Viện Sinh học nhiệt đới, Viện Hàn lâm KH \& CN Việt Nam \\ ${ }^{2}$ Đại học quốc tế, Đại học Quốc gia Tp. Hồ Chí Minh
}

\section{TÓM TẮT}

Nhấn tố ức chế bệnh bạch cầu (Lif) đóng vai trò rất quan trọng trong việc thiết lập các dòng tế bào gốc phôi, trong nghiên cứu này, chúng tôi khảo sát các tác động của Lif lên sự biểu hiện của các gene đa tiềm năng của tế bào gốc phôi bò ở mức phiên mã qua các thế hệ thứ 1,3 và 6 . Kết quả cho thấy, việc bổ sung Lif vào môi trường nuôi cấy tế bào có thể giúp tăng cường sự biểu hiện của các gene đa tiềm năng như nanog, $o c t 4$, sox2 và $c-m y c$ ở mức phiên mã. Ba nồng độ Lif đã được khảo sát trong nghiên cứu này cho thấy rằng các sản phẩm phiên mã của gene đa tiềm năng được biểu hiện cao nhất ở môi trường bổ sung Lif có nồng độ $10^{3} \mathrm{IU} / \mathrm{ml}$. Đặc biệt là sự biểu hiện sản phẩm phiên mã của gene nanog và oct4 có thể được duy trì tới lần cây chuyền thứ 6 . Sự biểu hiện sản phẩm phiên mã bị giảm ở môi trường nuôi cấy bổ sung $10^{4} \mathrm{IU} / \mathrm{ml}$ Lif, điều đó cho thấy nồng độ Lif cao có thể ức chế sự biểu hiện của gene đa tiềm năng. Do đó, môi trường bố sung Lif với nồng độ $10^{3} \mathrm{IU} / \mathrm{ml}$ hiệu quả nhất cho việc tăng cường sự biểu hiện của các gene đa tiềm năng. Trong nghiên cứu này, chúng tôi nhận thấy, sự biểu hiện của gene nanog giảm thì quá trình biểu hiện của các gene $c-m y c$ và sox-2 tăng. Kết quả đó chứng tỏ có mối quan hệ trong sự biểu hiện của gene nanog và $c-m y c$, sox-2.

Tư khóa: gene đa tiềm năng, nhân tố ức chế bệnh bạch cầu, rt-pcr, sự biểu hiện phiên mã, tế bào gốc phôi bò. Ngày nhận bài: 30-6-2013 